\title{
KARAKTERISTIK VEGETASI HABITAT ORANGUTAN (Pongo pygmaeus morio) DI HUTAN TEPI SUNGAI MENAMANG, KALIMANTAN TIMUR
}

\author{
VEGETATION CHARACTERISTICS OF THE ORANGUTAN (Pongo pygmaeus morio) \\ HABITAT IN THE RIPARIAN FOREST OF MENAMANG, EAST KALIMANTAN
}

\author{
Tri Sayektiningsih dan Amir Ma'ruf \\ Balai Penelitian Teknologi Konservasi Sumberdaya Alam \\ J1. Soekarno-Hatta, Km. 38, Balikpapan, Kalimantan Timur, telp. (0542) 7217663 \\ email: t.sayekti@yahoo.com, amirmaruf@hotmail.com
}

Diterima: 17 Pebruari 2017; direvisi: 06 Maret 2017; disetujui: 28 April 2017

\begin{abstract}
ABSTRAK
Penelitian dilakukan untuk memperoleh informasi mengenai komponen vegetasi habitat orangutan yang meliputi keanekaragaman jenis, komposisi, dan struktur vegetasi di hutan tepi Sungai Menamang. Pengumpulan data dilakukan dengan metode jalur berpetak. Hasil penelitian menunjukkan bahwa tingkat keanekagaman jenis pohon dan pancang adalah lebih tinggi dibandingkan semai. Pada tingkat pohon, Lagerstroemia speciosa memiliki nilai INP tertinggi, yaitu $24,71 \%$. Fordia splendidissima merupakan jenis dengan INP tertinggi pada tingkat pancang dengan INP $29,94 \%$. Selanjutnya, pada tingkat semai, Pterospermum diversifolium tumbuh dominan dengan INP 26,87\%. Secara umum, hutan tepi Sungai Menamang didominasi oleh pohon-pohon yang relatif muda yang dicirikan dengan melimpahnya pohon-pohon berdiameter $\geq 10-20 \mathrm{~cm}$ dan tinggi kurang dari $15 \mathrm{~m}$.

Kata kunci: hutan tepi sungai, Kalimantan Timur, Pongo pygmaeus morio, struktur dan komposisi vegetasi
\end{abstract}

\begin{abstract}
This study aimed to obtain information on vegetation characteristics of the orangutan's habitat, including diversity, composition and structure, in the riparian forest of Menamang. Data was collected using a line-plot sampling method. The diversity index of trees and saplings was higher than seedlings. It was found that Lagestroemia speciosa showed the highest value of IVI at tree stage, accounted for $24.71 \%$. Fordia splendidissima then was dominant species at sapling stage with IVI of $29.94 \%$. Furthermore, Pterospermum diversifolium grew in abundance at seedling stage with IVI of $26.87 \%$. Overall, vegetation in the research location was consisted by relatively young trees characterized by the abundance of trees with diameter of $\geq 10-20 \mathrm{~cm}$ and height of $<15 \mathrm{~m}$.

Keywords: riparian forest, East Kalimantan, Pongo pygmaeus morio, composition and structure of vegetation
\end{abstract}

\section{PENDAHULUAN}

Orangutan mendiami berbagai tipe habitat termasuk hutan hujan tropis dataran rendah, hutan rawa gambut, hutan tepi sungai dataran rendah, dan hutan rawa air tawar (Ancrenaz et al., 2004; Russon et al., 2001). Hal tersebut menyebabkan orangutan cenderung memiliki perilaku yang berbeda antar tipe habitat. Manduell et al. (2012) menyebutkan bahwa orangutan yang hidup di Ketambe, Sumatera dengan tipe hutan kering campuran cenderung menggunakan liana dengan diameter $>4 \mathrm{~cm}$ untuk mendukung aktivitas arboreal. Sebaliknya, orangutan di Sebangau, Kalimantan Tengah yang berciri hutan rawa gambut memilih untuk menghindari liana dengan diameter tersebut. Perbedaan perilaku antar tipe habitat salah satunya dipengaruhi oleh karakteristik vegetasi penyusunnya termasuk komposisi dan struktur vegetasi (Manduell et al., 2012).

Pongo pygmaeus morio atau orangutan morio merupakan salah satu sub-spesies orangutan yang terdapat di Pulau Kalimantan, khususnya Kalimantan bagian timur dan Sabah, Malaysia (Kanamori et al., 2017; Rayadin \& Spehar, 2015). Husson et al. (2009) menyebutkan bahwa rute distribusi sub-spesies ini dipengaruhi oleh aliran sungai Mahakam. Orangutan morio umumnya ditemukan di hutan hujan tropis dataran rendah (Ancrenaz et al., 2004). Namun, beberapa populasi diketahui hidup di kars, seperti di wilayah Sangkulirang, Kalimantan Timur (Marshall et al., 2007). Salah satu habitat orangutan morio di Kalimantan Timur adalah lanskap Kutai yang meliputi Taman Nasional Kutai dan wilayah disekitarnya, 
termasuk vegetasi di tepi Sungai Menamang (Sayektiningsih et al., 2013).

Hutan tepi sungai Menamang merupakan kawasan hutan yang terletak di tengah kawasan industri yang berkembang pesat. Disekitarnya, telah beroperasi berbagai konsesi seperti perkebunan kelapa sawit dan hutan tanaman industri (Acacia mangium) (Rayadin \& Spehar, 2015). Selain itu, kawasan ini juga berdekatan dengan pemukiman dan kebun masyarakat (Sayektiningsih et al., 2013). Hutan tepi sungai, khususnya pada yang telah didominasi manusia, memiliki peranan penting. Hutan tepi Sungai Menamang dapat berfungsi sebagai refuge area sekaligus habitat alternatif bagi satwa liar terdampak pembangunan (Martinez et al., 2015).

Penelitian terkait karakteristik vegetasi di hutan tepi sungai Menamang masih belum banyak dilakukan. Jenis penelitian yang pernah dilakukan pada kawasan ini umumnya bertujuan untuk mengetahui populasi dan karakteristik sarang orangutan (Sayektiningsih et al., 2013; Meijaard et al., 2010). Kurangnya informasi mengenai hutan tepi sungai Menamang akan berdampak pada kurangnya informasi mengenai karakteristik vegetasi penyusunnya (Sidiyasa, 2012). Di sisi lain, pembangunan industri dan pemukiman yang cepat dan cenderung mengabaikan prinsip-prinsip konservasi semakin mengancam kelestarian kawasan tersebut. Apabila tidak ditindaklanjuti, kondisi demikian akan berakibat pada semakin berkurangnya lebar dan luasan hutan. Oleh karena itu, penelitian ini bertujuan untuk mengetahui karakteristik vegetasi hutan tepi Sungai Menamang yang meliputi keanekaragaman jenis, serta komposisi dan struktur vegetasi. Informasi mengenai karakteristik vegetasi tersebut dapat dimanfaatkan untuk mendukung penelitian lebih lanjut seperti ekologi perilaku (Nawangsari et al., 2016). Selanjutnya, hasil penelitian juga bermanfaat untuk menaksir kesesuaian dan preferensi habitat orangutan. Hal ini sesuai dengan penelitian Rahman (2010) di Camp Leakey, Taman Nasional Tanjung Puting, Kalimantan Tengah, yang menyimpulkan bahwa karakteristik vegetasi berpengaruh terhadap preferensi habitat orangutan.

\section{METODE PENELITIAN}

Waktu dan lokasi penelitian

Penelitian dilaksanakan pada bulan Juni -

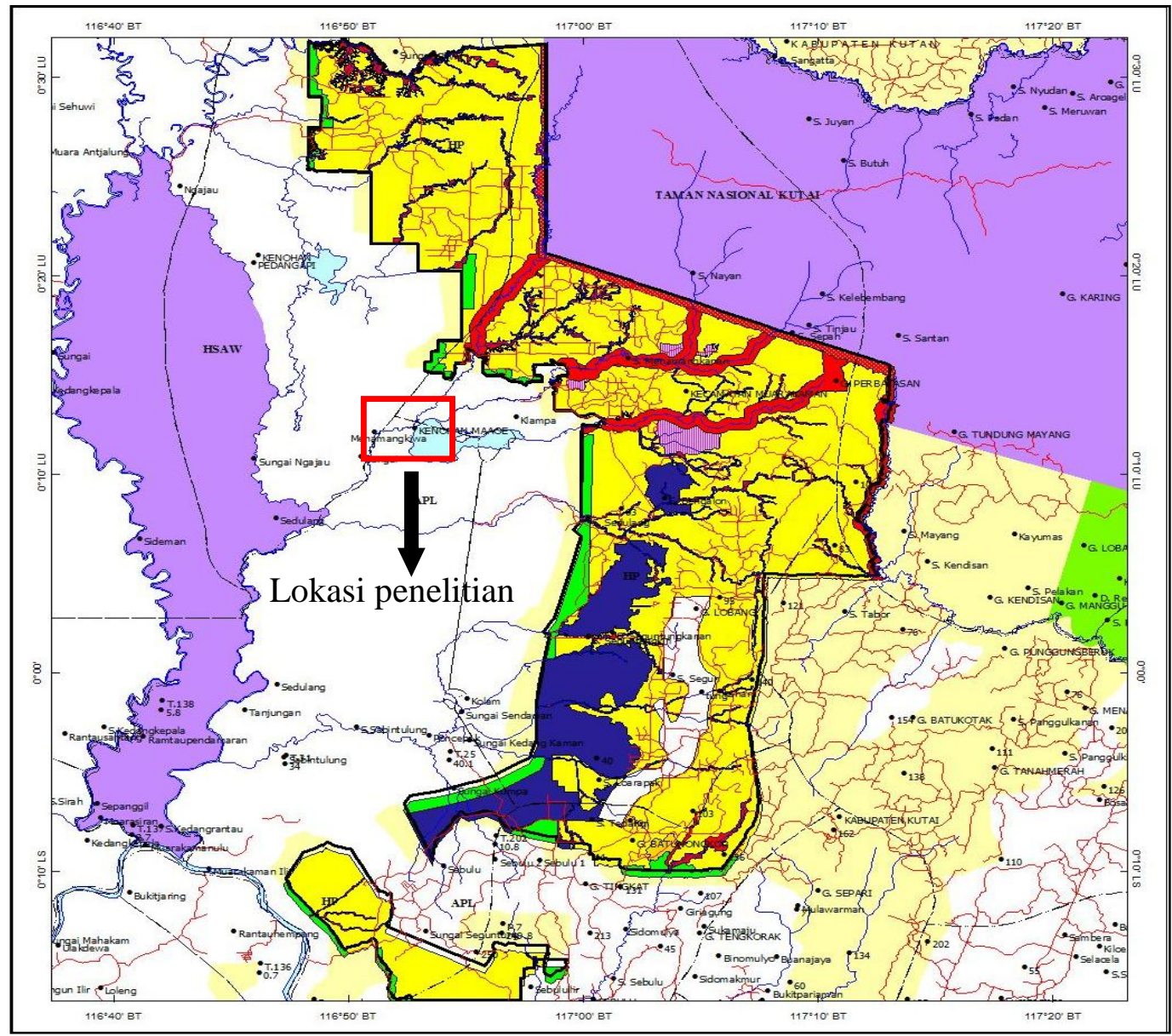

Gambar 1. Peta lokasi penelitian 
Nopember 2012 di sepanjang aliran Sungai Menamang yang berdekatan dengan Desa Menamang Kanan. Lokasi penelitian merupakan sebagian areal yang masuk ke dalam konsesi PT. Hamparan Sentosa.

Hutan tepi Sungai Menamang, secara administrasi, termasuk wilayah Kecamatan Muara Kaman, Kabupaten Kutai Kartanegara, Kalimantan Timur. Kondisi topografi hutan relatif datar dan selalu tergenang selama musim hujan. Rata-rata curah hujan setiap bulannya adalah 230, $88 \mathrm{~mm}$ dengan jumlah hari hujan 15 hari/bulan (Biro Pusat Statistik Kabupaten Kutai Kartanegara, 2014).

\section{Pengumpulan data}

Pengumpulan data vegetasi dilakukan dengan metode jalur berpetak. Tingkatan vegetasi yang diamati meliputi pohon $(\mathrm{DBH} \geq 10$, tidak termasuk tumbuhan berkayu pemanjat), pancang $(\mathrm{DBH}<10$, tinggi $\geq 1,5 \mathrm{~m}$, tidak termasuk tumbuhan berkayu pemanjat), dan semai (tinggi $<1,5 \mathrm{~m}$, termasuk tumbuhan berkayu dan herba) (Arbainsyah et al., 2014).

Jalur pengamatan diletakkan secara tegak lurus aliran sungai sepanjang $100 \mathrm{~m}$. Jarak antara jalur satu dengan lainnya adalah $200 \mathrm{~m}$. Untuk mempermudah pengambilan data, petak-petak pengamatan dibagi ke dalam sub-sub petak dengan ukuran $2 \mathrm{~m} \times 2 \mathrm{~m}$ untuk vegetasi pada tingkat semai, $5 \mathrm{~m} \times 5 \mathrm{~m}$ untuk vegetasi pada tingkat pancang, dan $20 \mathrm{~m}$ x $20 \mathrm{~m}$ untuk pengamatan vegetasi pada tingkat pohon. Karena kondisi hutan yang sudah terganggu, tidak semua jalur pengamatan berukuran $20 \mathrm{~m}$ x $100 \mathrm{~m}$. Secara keseluruhan telah dibuat 17 jalur pengamatan yang terdiri dari 75 petak pengamatan dengan luas 3 ha.

Seluruh jenis tumbuhan pada tingkat pohon dan pancang diidentifikasi, diukur diameter batang dan tingginya, sedangkan tumbuhan pada tingkat semai diidentifikasi jenis dan jumlahnya. Pengumpulan spesimen tumbuhan baik fertil maupun non fertil dilakukan untuk kepentingan identifikasi di Herbarium Wanariset Samboja, Kalimantan Timur.

\section{Analisis data}

Parameter analisis vegetasi yang digunakan meliputi indeks keanekaragaman jenis (H'), indeks kemerataan (E), kerapatan relatif (KR), frekuensi relatif (FR), dominansi relatif (DR). Indeks keanekaragaman jenis dihitung berdasarkan rumus Shannon-Wiener (Spellerberg dan Fedor, 2003):

$$
\mathrm{n}
$$

$\mathrm{H}^{\prime}=-\Sigma$ pi $\ln \mathrm{p}$
Dimana: H' adalah indeks keanekaragaman jenis, $\mathrm{p}_{\mathrm{i}}$ adalah jumlah individu spesies ke-i dibagi dengan jumlah total individu, dan ln adalah natural logaritma.

Sedangkan indeks kemerataan jenis (E) dihitung dengan rumus (Begon et al., 2006):

$\mathrm{E}=\mathrm{H}^{\prime} / \ln \mathrm{S}$

Dimana: E adalah indeks kemerataan jenis Pielou, H' adalah indeks keanekaragaman jenis, $\mathrm{S}$ adalah jumlah spesies, dan ln adalah natural logaritma.

Indeks Nilai Penting (INP) pohon dan pancang merupakan hasil penghitungan dari parameter $\mathrm{KR}+$ FR + DR. Sedangkan untuk vegetasi tingkat semai, indeks nilai penting diperoleh dengan cara menjumlahkan nilai kerapatan relatif dengan frekuensi relatif $(\mathrm{KR}+\mathrm{FR})$. Formula yang digunakan untuk menghitung parameter analisis vegetasi berdasarkan Bonham (2013).

\section{HASIL DAN PEMBAHASAN Keanekaragaman jenis}

Indeks keanekaragaman jenis diklasifikasikan sedang $\left(1>\mathrm{H}^{\prime}>3\right)$ pada tingkat semai dan tinggi ( $\mathrm{H}^{\prime}$ > 3) pada tingkat pancang dan pohon (Odum, 1993). Indeks keanekaragaman jenis pada tingkat semai lebih rendah dibandingkan tingkat pertumbuhan pancang dan pohon (Tabel 1). Rendahnya indeks tersebut dipengaruhi oleh lokasi hutan yang berdampingan dengan perkebunan kelapa sawit sehingga sumber benih hanya berasal dari pohon induk yang terdapat di dalam hutan. Secara umum, tingkat keanekaragaman jenis yang termasuk kategori sedang sampai tinggi mengindikasikan bahwa vegetasi tepi sungai Menamang memiliki tingkat resistensi dan resiliensi yang cukup baik jika terjadi gangguan (Lepš, 2013). Selain itu, mengingat hutan tepi Sungai Menamang merupakan salah satu habitat penting bagi orangutan pada lanskap yang telah terdegradasi (Meijaard et al., 2010), tingkat keanekaragaman jenis dengan kategori tersebut menunjukkan bahwa lokasi penelitian diduga mampu mendukung kebutuhan hidup orangutan seperti pakan, namun penelitian lebih lanjut mengenai aspek tersebut perlu dilakukan.

Menurut Arini dan Wahyuni (2016), indeks kemerataan jenis di lokasi penelitian dapat diklasifikasikan cukup merata pada tingkat semai $(0,51-0,75)$ dan hampir merata pada tingkat pancang dan pohon $(0,76$ - 0,95). Secara umum, besarnya indeks kemerataan yang masih berada pada kisaran 0 sampai 1 tersebut menunjukkan bahwa tidak ada spesies dominan di lokasi penelitian baik pada tingkat semai, pancang, dan pohon (Morris et al., 2014). 
Tabel 1. Indeks keanekaragaman dan kemerataan jenis pada berbagai tingkat pertumbuhan

\begin{tabular}{lcc}
\hline $\begin{array}{c}\text { Tingkat } \\
\text { Pertumbuhan }\end{array}$ & $\begin{array}{c}\text { Indeks } \\
\text { Keanekaragaman }\end{array}$ & $\begin{array}{c}\text { Indeks } \\
\text { Kemerataan }\end{array}$ \\
\hline Semai & 2,63 & 0,66 \\
Pancang & 3,67 & 0,80 \\
Pohon & 3,71 & 0,79 \\
\hline
\end{tabular}

\section{Komposisi vegetasi}

Vegetasi penyusun pada tingkat pohon terdiri dari 105 jenis, 68 genus, dan 38 suku. Euphorbiaceae merupakan suku yang paling umum dijumpai diikuti Verbenaceae, Moraceae, Lythraceae, dan Dilleniaceae. Sebanyak 137 pohon terindentifikasi sebagai anggota suku Euphorbiaceae. Lagerstroemia speciosa merupakan jenis dengan INP tertinggi (Tabel
2). Tingginya INP menunjukkan jenis tersebut memiliki tingkat kepentingan yang tinggi terhadap pemanfaatan unsur hara, tempat tumbuh, dan persebaran sehingga jumlahnya melimpah di lapangan (Sidiyasa, 2012; Atmoko \& Sidiyasa, 2008). Hal tersebut secara konsisten ditunjukkan dalam Tabel 2 bahwa jenis ini memiliki nilai tertinggi dalam hal kerapatan relatif, frekuensi relatif, dan dominansi relatif. Menurut Hashim dan Hughes (2010), hal tersebut dapat dipahami karena Lagerstroemia speciosa merupakan pohon spesialis hutan riparian dan memiliki tingkat pertumbuhan yang lebih cepat dibandingkan jenis lainnya. Selain faktor tersebut, Lagerstromia speciosa juga memiliki struktur biji bersayap (Keßler dan Sidiyasa, 1999). Penyebaran biji dengan struktur demikian umumnya dibantu angin sehingga mampu mencakup wilayah yang luas.

Tabel 2. Sepuluh jenis pohon utama berdasarkan INP di lokasi penelitian

\begin{tabular}{|c|c|c|c|c|c|c|}
\hline No & Jenis & $\begin{array}{l}\text { KR } \\
(\%)\end{array}$ & $\begin{array}{l}\text { FR } \\
(\%)\end{array}$ & $\begin{array}{l}\text { DR } \\
(\%)\end{array}$ & $\begin{array}{c}\text { INP }(I V I) \\
(\%)\end{array}$ & Suku \\
\hline 1. & Lagerstroemia speciosa (L.) Pers. & 9,67 & 6,15 & 8,89 & 24,71 & Lythraceae \\
\hline 2. & Vitex pinnata $\mathrm{L}$ & 6,33 & 4,55 & 7,02 & 17,90 & Verbenaceae \\
\hline 3. & Dracontomelon dao (Blanco) Merr. \& Rolfe & 5,00 & 5,88 & 5,98 & 17,79 & Anacardiaceae \\
\hline 4. & Peronema canescens Jack. & 8,33 & 0,80 & 6,17 & 15,30 & Lamiaceae \\
\hline 5. & Dillenia excelsa (Jack) Gilg & 7,56 & 4,54 & 2,60 & 14,70 & Dilleniaceae \\
\hline 6. & Cananga odorata (Lam.) Hook.f. \& Thomson & 4,89 & 4,01 & 4,69 & 13,59 & Annoaceae \\
\hline 7. & Artocarpus elasticus Reinw.ex Blume & 4,67 & 3,48 & 3,26 & 11,41 & Moraceae \\
\hline 8. & Syzygium sp1. & 3,89 & 2,67 & 2,14 & 8,70 & Myrtaceae \\
\hline 9. & Macaranga gigantea (Reichb.f. \& Zoll.) Muell.Arg. & 3,56 & 2,41 & 2,67 & 8,64 & Euphorbiaceae \\
\hline 10. & Lithocarpus $\mathrm{sp} 1$ & 2,44 & 2,67 & 2,83 & 7,94 & Fagaceae \\
\hline
\end{tabular}

Keterangan:

$\mathrm{KR}=$ kerapatan relatif, $\mathrm{FR}=$ frekuensi relatif, $\mathrm{DR}=$ dominansi relatif, $\mathrm{INP}=$ indeks nilai penting

Pada tingkat pancang, vegetasi tersusun dari 97 jenis, 76 genus, dan 41 suku. Pada tingkatan ini, beberapa suku seperti Leguminosae, Leeaceae, Dilleniaceae, Euphorbiaceae, dan Myrtaceae diketahui tumbuh dominan. Jenis Fordia splendidissima merupakan jenis dengan INP tertinggi (Tabel 2). Selanjutnya di tingkat semai, komposisi vegetasi terdiri dari 55 jenis, 45 genus, dan 30 suku dengan Pterospermum diversifolium sebagai jenis dengan tingkat kepentingan tertinggi (Tabel 3).

Hasil penelitian menunjukkan bahwa terdapat kecenderungan dimana jumlah jenis, genus, dan suku pada tingkat pancang lebih banyak daripada jumlah tersebut di tingkat semai. Tetapi, jumlah genus dan suku cenderung menurun dari pancang ke pohon. Kondisi demikian dapat dijelaskan dengan mengaitkannya dengan keberadaan jenis pionir dan jenis asli (Hidayat, 2013). Hutan tepi sungai Menamang diperkirakan pernah mengalami gangguan di masa lalu sehingga sekarang hutan ini dapat diklasifikasikan sebagai hutan sekunder. Pada tipe hutan ini jenis-jenis pionir dan semak umum ditemukan. Beberapa jenis pohon seperti Lagerstroemia speciosa, macaranga, dan kehadiran Fordia splendidissima mendukung kondisi tersebut (Yassir et al., 2010; Hashim dan Hughes, 2010). Seiring dengan proses pertumbuhan, jenis-jenis pionir akan akan tumbuh bersamaan dengan jenis-jenis asli sehingga jumlah jenis, marga, dan suku akan bertambah (Hidayat, 2013). Fenomena ini tampaknya terus berlangsung sampai ke tingkat pohon dimana jumlah jenis pada tingkat ini lebih banyak daripada jumlah jenis di tingkat pancang. Walaupun demikian, pertambahan jenis tampaknya hanya berasal dari marga atau suku yang sama. Sehingga, pada tingkat pohon jumlah marga dan suku tidak bertambah atau cenderung menurun. 
Selama penelitian tercatat 900 pohon, 885 pancang, dan 1.069 semai. Hasil tersebut mencerminkan bahwa regenerasi pohon-pohon di lokasi penelitian cukup ideal dimana jumlah semai lebih banyak dibandingkan pancang (Sidiyasa, 2009). Rendahnya jumlah pancang diduga berkaitan dengan kondisi topografi yang landai. Pada musim hujan, kondisi hutan sebagian besar akan tergenang air dalam waktu yang cukup lama. Hal tersebut tentunya dapat mempengaruhi proses pertumbuhan dan perkembangan semai yang selanjutnya berpengaruh terhadap jumlah pancang.

Tabel 3. Sepuluh jenis utama pada tingkat pancang berdasarkan INP

\begin{tabular}{llccccc}
\hline No & \multicolumn{1}{c}{ Jenis } & $\begin{array}{c}\text { KR } \\
(\boldsymbol{\%})\end{array}$ & $\begin{array}{c}\text { FR } \\
(\boldsymbol{\%})\end{array}$ & $\begin{array}{c}\text { DR } \\
(\boldsymbol{\%})\end{array}$ & $\begin{array}{c}\text { INP } \\
(\boldsymbol{I V I})\end{array}$ & Suku \\
\hline 1. & Fordia splendidissima (Bl. ex Miq.) Buijsen & 15,25 & 6,31 & 8,38 & 29,94 & Leguminosae \\
& subsp. Splendidissim & & & & & \\
2. & Leea indica (Burm.f.) Merr. & 10,85 & 5,41 & 4,80 & 21,06 & Leeaceae \\
3. & Dillenia excelsa (Jack) Gilg & 4,41 & 4,20 & 4,50 & 13,11 & Dilleniaceae \\
4. & Macaranga tanarius (L.) Mull.Arg. & 4,18 & 1,80 & 7,09 & 13,07 & Euphorbiaceae \\
5. & Cleistanthus myrianthus Kurz & 4,18 & 1,80 & 6,22 & 12,20 & Euphorbiaceae \\
6. & Syzygium sp. & 2,60 & 5,41 & 3,16 & 11,17 & Myrtaceae \\
7. & Mitragyna speciosa Korthals & 2,26 & 1,20 & 6,13 & 9,59 & Rubiaceae \\
8. & Clerodendrum sp. & 3,05 & 2,70 & 2,67 & 8,42 & Verbenaceae \\
9. & Litsea sp. & 1,81 & 1,80 & 4,41 & 8,02 & Lauraceae \\
10. & Nauclea sp. & 3,05 & 2,40 & 2,39 & 7,84 & Rubiaceae \\
\hline
\end{tabular}

Keterangan:

$\mathrm{KR}=$ kerapatan relatif, $\mathrm{FR}=$ frekuensi relatif, $\mathrm{DR}=$ dominansi relatif, $\mathrm{INP}=$ indeks nilai penting

Tabel 4. Sepuluh jenis utama pada tingkat semai berdasarkan INP

\begin{tabular}{|c|c|c|c|c|c|}
\hline No & $\begin{array}{c}\text { Jenis } \\
(\text { Species })\end{array}$ & $\begin{array}{l}\text { KR } \\
(\%)\end{array}$ & $\begin{array}{l}\text { FR } \\
(\%)\end{array}$ & $\begin{array}{l}\operatorname{INP}(I V I) \\
\quad(\%)\end{array}$ & $\begin{array}{c}\text { Suku } \\
\text { (Family) }\end{array}$ \\
\hline 1. & Pterospermum diversifolium Blume & 24,04 & 2,82 & 26,87 & Sterculiaceae \\
\hline 2. & Pternandra sp. & 21,33 & 3,39 & 24,72 & Melastomataceae \\
\hline 3. & $\begin{array}{l}\text { Fordia splendidissima (Bl. ex Miq.) Buijsen subsp. } \\
\text { Splendidissim }\end{array}$ & 8,98 & 12,99 & 21,97 & Leguminosae \\
\hline 4. & Syzygium sp1. & 8,89 & 9,04 & 17,93 & Myrtaceae \\
\hline 5. & Leea indica (Burm.f.) Merr. & 4,77 & 7,34 & 12,11 & Leeaceae \\
\hline 6. & Pterospermum javanicum Jungh. & 4,68 & 6,21 & 10,89 & Sterculiaceae \\
\hline 7. & Syzygium sp2. & 2,99 & 3,38 & 6,38 & Myrtaceae \\
\hline 8. & Ficus obscura Blume & 2,90 & 3,39 & 6,29 & Moraceae \\
\hline 9. & Ficus sp. & 2,43 & 2,82 & 5,25 & Moraceae \\
\hline 10. & Lepisanthes amoena (Hassk.) Leenh. & 0,74 & 3,39 & 4,13 & Sapindaceae \\
\hline
\end{tabular}

Keterangan:

$\mathrm{KR}=$ kerapatan relatif, $\mathrm{FR}=$ frekuensi relatif, $\mathrm{DR}=$ dominansi relatif, $\mathrm{INP}=$ indeks nilai penting

\section{Struktur vegetasi}

Hutan tepi Sungai Menamang merupakan hutan sekunder yang dicirikan dengan kerapatan pohon 300 pohon/ha dan basal area $12,34 \mathrm{~m}^{2} / \mathrm{ha}$. Menurut Ancrenaz et al. (2004), kondisi kerapatan dan basal area tersebut termasuk kategori rendah. Pohon-pohon di lokasi penelitian menyebar pada berbagai kelas diameter dan didominasi oleh pohon-pohon berdiameter $\geq 10-20 \mathrm{~cm}$ (551 pohon) (Gambar 3). Beberapa jenis pohon berdiameter besar dengan diameter $\geq 70 \mathrm{~cm}$ yang teridentifikasi adalah
Lagerstroemia speciosa, Dracontomelon dao, Antiaris toxicaria, dan Ixonanthes reticulata.

Kondisi hutan yang terbuka merupakan salah satu faktor penyebab dominannya pohon dengan diameter kecil. Seperti diketahui, vegetasi tepi Sungai Menamang memiliki tutupan kanopi yang kurang rapat sehingga memungkinkan sinar matahari menembus lantai hutan. Kondisi ini akan merangsang proses regenerasi benih-benih pohon yang toleran terhadap sinar matahari sehingga pohon-pohon berdiameter kecil umum ditemukan (Sidiyasa, 2009). 


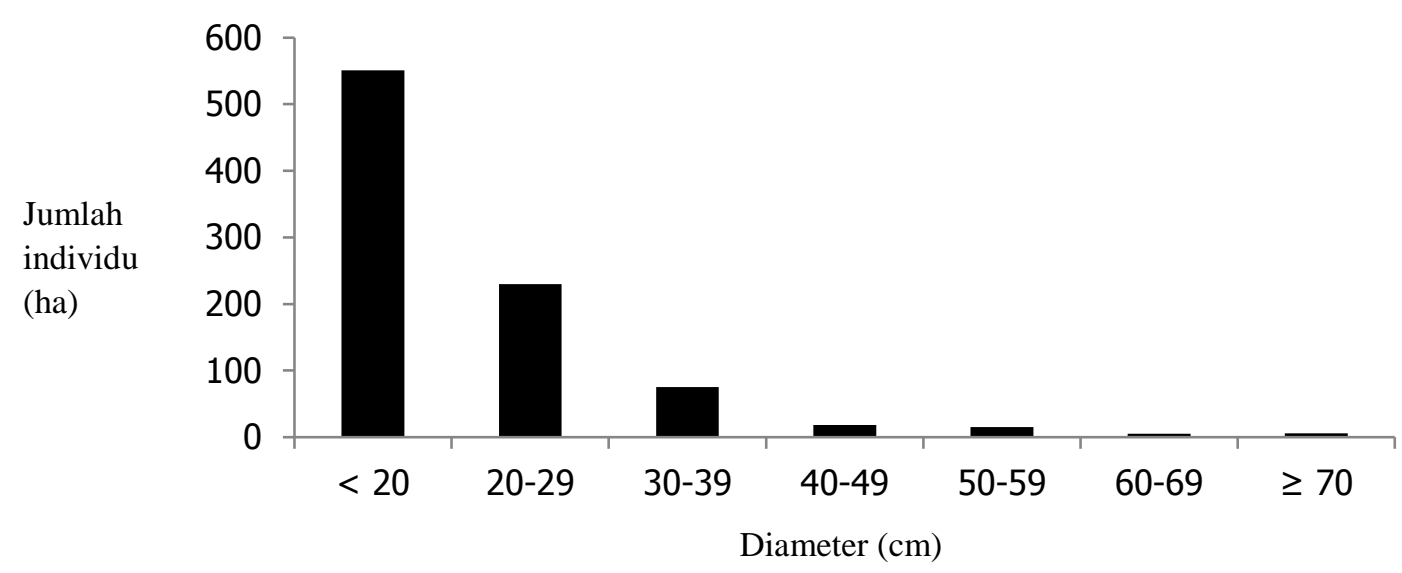

Gambar 2. Sebaran diameter pohon di lokasi penelitian

Tinggi pohon di lokasi penelitian umumnya menyebar pada rentang satu sampai dengan $35 \mathrm{~m}$ dan memiliki rerata $13,65 \mathrm{~m}$ (SD 3,59). Pohon-pohon dengan ketinggian kurang dari $15 \mathrm{~m}$ memiliki jumlah yang melimpah (536 pohon). Keberadaan pohonpohon dengan ketinggian lebih dari $35 \mathrm{~m}$ tidak banyak ditemukan. Terdapat satu jenis pohon dengan ketinggian lebih dari $35 \mathrm{~m}$, yaitu Ixonanthes reticulata. Kecenderungan penambahan tinggi pohon yang berbanding lurus dengan penambahan kelas diameter dan berbanding terbalik dengan jumlah individu dapat ditemui di lokasi penelitian (Gambar 4). Pola tersebut semakin memperjelas bahwa hutan tepi Sungai Menamang didominasi oleh pohon-pohon yang relatif muda.

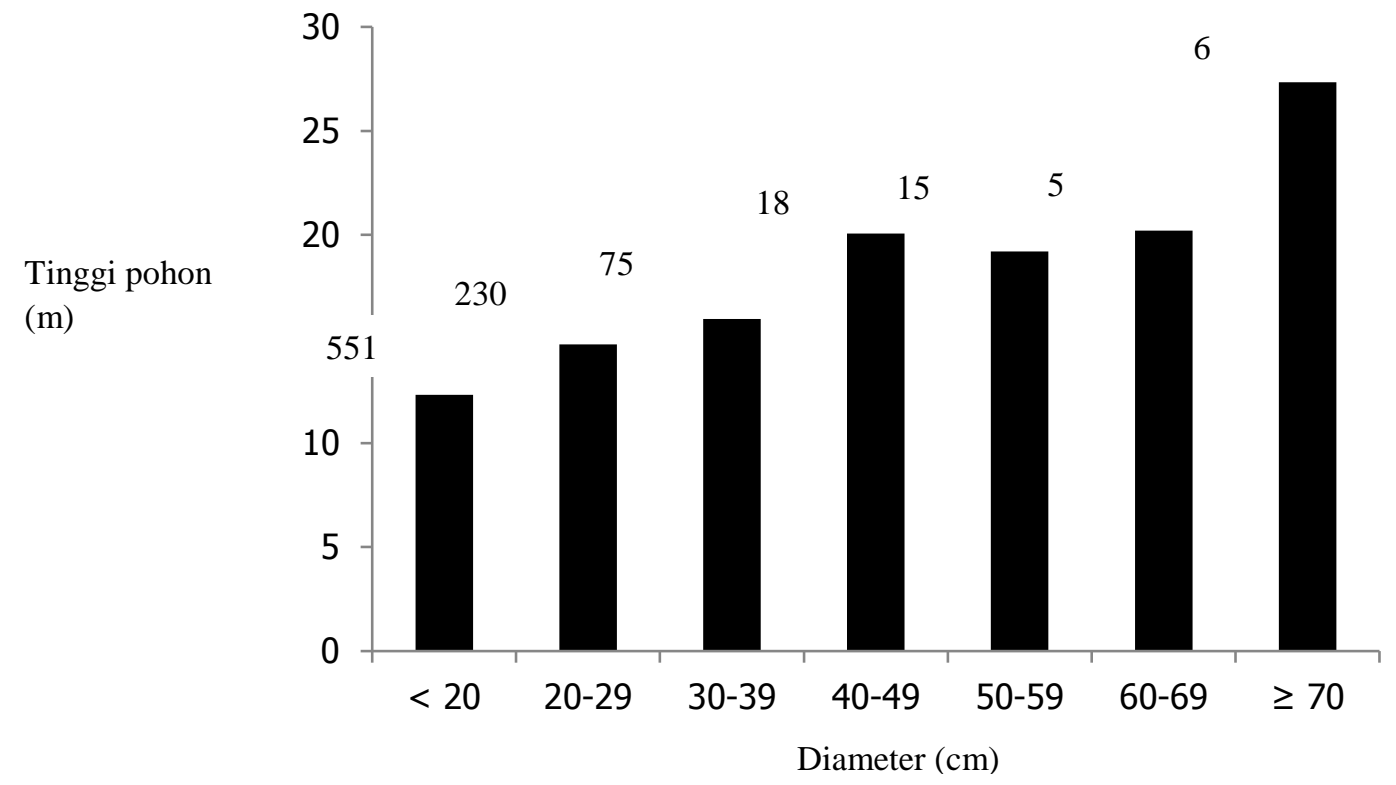

Gambar 3. Hubungan antara tinggi pohon dan kelas diameter

\section{Fungsi vegetasi bagi orangutan}

Orangutan memanfaatkan tumbuh-tumbuhan hutan sebagai sumber pakan. Beberapa jenis pohon di lokasi penelitian yang berpotensi sebagai pakan orangutan disajikan dalam Tabel 4. Beberapa jenis diantaranya bahkan memiliki nilai INP tinggi baik pada tingkat pohon, pancang, dan semai.
Selain sebagai sumber pakan, tumbuh-tumbuhan hutan juga dimanfaatkan sebagai tempat bersarang. Selama observasi, sarang-sarang orangutan ditemukan pada pohon Lagerstroemia speciosa, Vitex pinnata, Dracontomelon dao, Dillenia excelsa, Cananga odorata, dan Macaranga gigantea. Sarang-sarang tersebut terletak di cabang utama, ujung dahan, dan 
pucuk pohon. Umumnya, orangutan hanya membuat satu sarang pada satu pohon. Perjumpaan dengan sarang orangutan cukup menarik dimana orangutan terlihat memanfaatkan jenis pohon yang sama sebagai sumber pakan dan tempat bersarang. Namun, menurut Prasetyo et al. (2009), orangutan umumnya cenderung menghindari perilaku tersebut. Fenomena yang terjadi diduga dipengaruhi oleh kondisi habitatnya. Saat ini tutupan vegetasi tepi Sungai Menamang tidak kontinu dan terbuka. Dalam kondisi lingkungan demikian, orangutan akan berusaha untuk meminimalkan pengeluaran energi yang digunakan sehingga pemanfaatan pohon pakan sebagai tempat bersarang sekaligus merupakan salah satu pilihan (Russon, 2010).

Hutan yang semakin menyempit dan terdegradasi di Kalimantan Timur menyebabkan orangutan kehilangan habitat dan sumber pakan. Sebagai akibatnya, frekuensi orangutan memasuki areal konsesi seperti perkebunan kelapa sawit meningkat. Di areal perkebunan kelapa sawit orangutan biasanya mencari sumber pakan alternatif, seperti umbut, untuk memenuhi kebutuhan nutrisinya. Crop raiding tersebut memicu terjadinya konflik, seperti di Puan Cepak, Kabupaten Kutai Kartanegara yang cenderung merugikan orangutan. Berdasarkan hal tersebut, hutan tepi Sungai Menamang berperan penting untuk mencegah konflik antara orangutan dengan manusia. Seiring dengan upaya perlindungan dan pengelolaan yang tepat, keberadaan pohon-pohon berpotensi pakan orangutan di lokasi penelitian akan tumbuh dan berkembang dengan baik sehingga dapat menyediakan buah-buahan yang merupakan sumber pakan utama orangutan.

Tabel 4. Jenis-jenis tumbuhan yang berpotensi sebagai pakan orangutan

\begin{tabular}{|c|c|c|}
\hline Tingkat & Jenis & \\
\hline Semai & $\begin{array}{l}\text { *Ficus obscura Blume, } \\
\text { * Lepisanthes amoena (Hassk.) Leenh., *Fordia } \\
\text { splendidissima (Bl. ex Miq.) Buijsen subsp. } \\
\text { Splendidissim, *Leea indica (Burm.f.) Merr., Dillenia } \\
\text { excelsa (Jack) Gilg, *Pterospermum javanicum Jungh., } \\
\text { Dracontomelon dao Blanco) Merr. \& Rolfe }\end{array}$ & $\begin{array}{l}\text { Pohan (2016); Kelle et al. (2014), } \\
\text { Ferisa (2014), Aini (2011), Marshall } \\
\text { et al. (2009), Ferisa dan Indrayana } \\
\text { (2007) }\end{array}$ \\
\hline Pancang & $\begin{array}{l}\text { *Fordia splendidissima (Bl. ex Miq.) Buijsen subsp. } \\
\text { Splendidissim, *Leea indica (Burm.f.) Merr, *Dillenia } \\
\text { excelsa (Jack) Gilg, Artocarpus elasticus Reinw.ex } \\
\text { Blume, Ficus obscura Blume, Lepisanthes amoena } \\
\text { (Hassk.) Leenh., Pterospermum javanicum Jungh., } \\
\text { Macaranga gigantea (Rchb.f.and Zoll.) Mull.Arg., } \\
\text { Cananga odorata (Lam.) Hook.f. \& Thomson, } \\
\text { Dracontomelon dao (Blanco) Merr. \& Rolfe, Vitex } \\
\text { pinnata L., Kleinhovia hospita L., Vatica rassak } \\
\text { (Korth.) Blume }\end{array}$ & \\
\hline Pohon & $\begin{array}{l}\text { Pterospermum javanicum Jungh., *Dillenia excelsa } \\
\text { (Jack) Gilg, *Artocarpus elasticus Reinw.ex Blume, } \\
\text { Kleinhovia hospita L., Macaranga gigantea } \\
\text { (Rchb.f.and Zoll.) Mull.Arg., *Vitex pinnata L., } \\
\text { *Dracontomelon dao (Blanco) Merr. \& Rolfe, } \\
\text { *Cananga odorata (Lam.) Hook.f. \& Thomson, } \\
\text { Artocarpus dadah Miq., Geunsia pentandra (Roxb.) } \\
\text { Merr., Ficus obscura Blumea, Antiaris toxicaria (Pers.) } \\
\text { Lesch., Dillenia reticulata King, Endospermum } \\
\text { diadenum (Miq.) Airy Shaw, Vatica rassak (Korth.) } \\
\text { Blume }\end{array}$ & \\
\hline
\end{tabular}

*Jenis yang memiliki nilai INP tinggi seperti pada tabel 2, 3, dan 4 


\section{KESIMPULAN}

Hutan tepi Sungai Menamang merupakan hutan sekunder yang memiliki kerapatan dan basal area yang rendah. Keanekaragaman jenis pada tingkat semai tergolong sedang. Sedangkan, pancang dan pohon memiliki keanekaragaman jenis yang tinggi Indeks kemerataan jenis memiliki nilai antara 0 sampai 1 baik pada tingkat semai, pancang, dan pohon. Berdasarkan nilai INP, vegetasi tersusun oleh jenis-jenis dominan, yaitu Lagerstroemia speciosa pada tingkat pohon, Fordia splendidissima pada tingkat pancang, dan Pterospermum diversifolium pada tingkat semai. Pohon-pohon di dalam hutan didominasi oleh pohon berdiameter $\geq 10-20 \mathrm{~cm}$. Sebagian besar, pohonpohon di kawasan ini mempunyai tinggi $<15 \mathrm{~m}$.

\section{SARAN}

Penelitian ini memiliki keterbatasan karena hanya mengukur keanekaragaman, serta komposisi dan struktur vegetasi sehingga hasil yang diperoleh masih berupa informasi awal. Untuk itu diperlukan penelitian lanjutan yang berkaitan dengan keanekaragaman jenis pakan yang tidak terbatas pada pohon. Selain itu, penelitian tentang karakteristik floristik pohon-pohon potensial pakan orangutan juga diperlukan karena dapat digunakan untuk mengetahui waktu berbuah serta kuantitasnya. Informasi mengenai populasi orangutan di lokasi penelitian juga perlu diketahui sehingga hasil penelitian mengenai karakteristik vegetasi dan keanekaragaman jenis pakan dapat digunakan untuk menaksir daya dukung kawasan terhadap populasi orangutan.

\section{UCAPAN TERIMA KASIH}

Penulis mengucapkan terima kasih kepada rekan-rekan teknisi yang membantu pengumpulan data di lapangan, manajemen PT Hamparan Sentosa yang memberikan ijin kepada tim peneliti untuk mengambil data, dan masyarakat Desa Menamang Kanan yang bersedia menerima kehadiran tim peneliti dan membantu akomodasi.

\section{DAFTAR PUSTAKA}

Aini, F. (2011). Preferensi dan kandungan nutrisi pakan orangutan Sumatera (Pongo abelii Lesson, 1827) di Stasiun Penelitian Hutan Lindung Batang Toru, Tapanuli Tengah, Sumatera, Utara. Skripsi tidak dipublikasikan, Institut Pertanian Bogor, Bogor.

Ancrenaz, M., Calaque, R., and Lackman, I. (2004). Orangutan nesting behavior in disturbed forest of Sabah, Malaysia: Implications for nest census. International Journal of Primatology, 25(5), 983 1000 .
Arbainsyah, de Iongh, H. H., Kustiawan, W., and de Snoo, G. R. (2014). Structure, composition and diversity of plant communities in FSC-certified, selectively logged forests of different ages compared to primary rain forest. Biodiversity Conservation, 23, 2445 2472. doi: 10.1007/s10531-014-0732-4

Arini, D. I. D., dan Wahyuni, N. I. (2016). Kelimpahan tumbuhan pakan anoa (Bubalus sp.) di Taman Nasional Bogani Nani Wartabone. Jurnal Penelitian Kehutanan Wallacea, 5(1), 91 - 102.

Atmoko, T., dan Sidiyasa, K. (2008) Karakteristik vegetasi habitat bekantan (Nasalis larvatus Wurmb) di Delta Mahakam, Kalimantan Timur. Jurnal Penelitian Hutan dan Konservasi Alam, 5(4), 307 - 316.

Begon, M., Townsend, C. R., and Harper, J. L. (2006). Ecology: From Individuals to Ecosystems. Blackwell Publishing.

Biro Pusat Statistik Kabupaten Kutai Kartanegara. (2014). Kecamatan Muara Kaman dalam angka. Biro Pusat Statistik Kabupaten Kutai Kartanegara.

Bonham, C. D. (2013). Measurements for Terestrial Vegetation. Colorado: Willey-Black Well.

Ferisa, A. (2014). Pemanfaatan ruang oleh orangutan Pongo pygmaeus morio (Owen, 1837) di Stasiun Penelitian Mentoko dan Prefab Taman Nasional Kutai Kalimantan Timur. Tesis tidak dipublikasikan, Sekolah Pasca Sarjana Institut Pertanian Bogor, Bogor.

Ferisa, A., dan Indrayana. (2007). Daftar Pakan Orangutan di Sekolah Hutan II Samboja. Orangutan Social Learning and Cultures Project.

Hashim, N. R., \& Hughes, F. M. R. (2010). The responses of secondary forest tree sedlings to soil enrichment in Peninsular Malaysia: an experimental approach. Tropical Ecology, 51(2), 173 - 182.

Hidayat, S. (2013). Kondisi vegetasi di kawasan hutan kebun raya Balikpapan. Berita Biologi, 12(3), 345 357.

Husson, S. J., Wich, S. A., Marshall, A. J., Dennis, R. D., Ancrenaz, M., Singleton, I. (2009). Orangutan distribution, density, abundance and impacts of disturbance. In S. A. Wich, S. S. U. Atmoko, T. M. Setia, \& C. P. van Schaik (Eds), Orangutans Geographic Variation in Behavioural Ecology and Conservation (pp. 97-117). Oxford: Oxford University Press.

Kanamori, T., Kuze, N., Bernard, H., Malim, T. P., and Kohshima, S. (2017). Fluctuation of population densisty of Bornean orangutans (Pongo pygmaeus morio) related to fruit availability in the Danum Valley, Sabah, Malaysia: a 10-year record including two mast fruiting and three other peak fruitings. Primate, 58, 225 - 235. doi: 10.1007/s10329-0160584-5

Kelle, D., Gärtner, S., Pratje, P. H., and Storch, I. (2014). Reintroduced Sumatran orangutans (Pongo abelii): using major food tree species as indicators of habitat 
suitability. Folia Primatology, 85, 90 - 108. doi: 10.1159/000357498

Keßler, P. J. A., \& Sidiyasa, K. (1999). Pohon-pohon Hutan Kalimantan Timur: Pedoman Mengenal 280 Jenis Pohon Pilihan di Daerah Balikpapan-Samarinda. Indonesia: MOFEC-Tropenbos-Kalimantan Project.

Lepš, J. (2013). Diversity and ecosystem function. In E. van der Maarel, J. Franklin (eds). Vegetation Ecology (pp. 308 - 341). UK: Wiley-Blackwell.

Manduell, K. L., Harrison, M. E., \& Thorpe, S. K. S. (2012). Forest structure and support availability influence orangutan locomotion in Sumatra and Borneo. American Journal of Primatology, 74, 1128 - 1142.

Marshall, A. J., Ancrenaz, M., Brearley, F. Q., Fredriksson, G. M., Ghaffar, N., Heydon, M., Wich, S. A. (2009). The effects of forest phenology and floristics on populations of Bornean and Sumatran orangutans. In S. A. Wich, S. S. U. Atmoko, T. M. Setia, \& C. P. van Schaik (Eds), Orangutans Geographic Variation in Ecology and Conservation (pp. 97 117). Oxford: Oxford University Press.

Martinez, M. A. G., Sarria, F. E., Barrera, F. L., Meneses, G. C., \& Gonzales, J. E. V. (2015). Value of riparian vegetation remnants for leaf-litter ants (Hymenoptera: Formicidae) in a human-dominated landscape in Central Veracruz, Mexico. Community and Ecosystem Ecology, 44(6), 1488 - 1497.

Marshall., A. J., Salas, L. A., Stephens, S., Nardiyono, Engstrom, L., Meijaard, E., and Stanley. (2007). Use of limestone karst forests by Bornean orangutans (Pongo pygmaeus morio) in the Sangkulirang Peninsula, East Kalimantan, Indonesia. American Journal of Primatology, 69, 1 - 8.

Meijaard, E., Albar, G., Nardiyono, Rayadin, Y., Ancrenaz, M., \& Spehar, S. (2010). Unexpected ecological resilience in Bornean Orangutans and Implications for pulp and paper plantation management. Plos One, 5(9), $1-7$.

Morris, E. K., Caruso, T., Buscot, F., Fischer, M., Hancock, C., Maier, T. S....Rillig, M. C. (2014). Choosing and using diversity indices: insight for ecological applications from the German Biodiversity Exploratories. Ecology and Evolution, 4(18), 3514 3524. doi: 10.1002/ece3.1155

Nawangsari, V. A., Mustari, A. H., \& Masyud, B. (2016). Pengelolaam pasca pelepasliaran dan aktivitas orangutan (Pongo pygmaeus wurmbii Groves, 2001) ex-captive di Suaka Margasatwa Lamandau. Media Konservasi, 12(1), 36 - 41.

Odum, E. P. (1993). Dasar-dasar Ekologi. Yogyakarta: Gadjah Mada University Press.

Pohan, M. R. Z. S. D. (2016). Analisis pakan orangutan (Pongo abelii) di Taman Nasional Gunung Leuser Resort Sei Betung Sumatera Utara. Jurnal Biosains, 2(2), 97 - 103
Prasetyo, D., Ancrenaz, M., Morrogh-Bernard, H. C., Atmoko, S. S. U., Wich, S. A., and van Schaik, C. P. (2009). Nest Building in Orangutan. In S. A. Wich; S. S. U Atmoko; T.M. Setia; C. P. van Schaik, editor. Orangutans Geographic Variation in Bahavioral Ecology and Conservation (pp. 269 - 278). Oxford: Oxford University Press.

Rahman, D. A. (2010). Karakteristik habitat dan preferensi pohon sarang orangutan (Pongo pygmaeus wurmbii) di Taman Nasional Tanjung Putting (studi kasus Camp Leakey). Jurnal Primatologi Indonesia, 7(2), $37-50$.

Rayadin, Y., and Spehar, S. N. (2015). Brief communication: body mass of wild Bornean orangutans living in human-dominated landscape: implications for understanding their ecology and conservation. American Journal of Physical, Anthropology, 157, 339 - 346.

Russon, A. E. (2010). Life history: the energy-efficient orangutan. Current Biology, 20(22). doi: 10.1016/j.cub.2010.10.003

Russon, A. E., Erman, A., \& Dennis, R. (2001). The population and distribution of orangutans (Pongo pygmaeus pygmaeus) in and around the Danau Sentarum Wildlife Reserve, West Kalimantan, Indonesia. Biological Conservation, 97, 21 - 28.

Sayektiningsih, T., Rayadin, Y., Ma'ruf, A., \& Yassir, I. (2013). Nest characteristics and prospect of orangután (Pongo pygmaeus morio) corridor establishment in Menamang Forest, East Kalimantan, Indonesia. In Langi, M., Tasirin, J. S., Walangitan, H. J., \& Masson, G. (eds), Proceeding International Conference "Forest and Biodiversity" (pp. 49 - 58.). Manado: Manado Forestry Research Institute.

Sidiyasa, K. (2012). Karakteristik hutan rawa gambut di Tuanan dan Katunjung, Kalimantan Tengah. Jurnal Penelitian Hutan dan Konservasi Alam, 9(2), 125 137.

Sidiyasa, K. (2009). Struktur dan komposisi tegakan serta keanekaragamannya di Hutan Lindung Sungai Wain, Balikpapan, Kalimantan Timur. Jurnal Penelitian Hutan dan Konservasi Alam, 6(1), 79 93.

Spellerberg, A, F. \& Fedor, P. (2003). A tribute to Claude Shannon (1916-2001) and more rigorous use of species richness, species diversity, and the 'Shannon-Wiener'Index. Global Ecology \& Biogeography, 12, 177 - 179.

Yassir, I., van der Kamp. J., \& Buurman, P. (2010). Secondary succession after fire in Imperata grasslands of East Kalimantan, Indonesia. Agriculture, Ecosystems and Environment, 137, 172 $-182$. 
Jurnal WASIAN Vol.4 No.1 Tahun 2017:17-26 